\title{
EARLY SUGGESTIONS OF THE MODERN WRITTEN CONSTITUTION.
}

In a former number of this Journal, the present writer called attention to the gradual development of the Supreme Court's clearly acknowledged power to declare void an act of Congress inconsistent with the Constitution. Not only, however, can this judicial function claim a remote origin, but the scheme itself of a written constitution is far from being a modern invention and strikes its roots far into the past, being illustrated, in fact, at more than one period of distinct importance to the history of constitutional law. Nor shall the failure of these ancient attempts to establish a basis of government which has proved so successful in modern times, render the constitutional plans themselves less worthy of attention on the part of all interested in institutional origins.

The publication, in $189 \mathrm{I}$, of the recovered constitution of Athens - $A \theta \eta v \alpha i$ wo $\pi$ onzzeía - brought to light the details of the remarkable machinery by which it was sought to place the government devised by the revolutionists of the spring of B.C. 4II under the limitations of a written plan whose essential principles, from a constitutional standpoint, are those of the limited constitution of to-day. For this apparently radical departure in public administration the Athenian mind had, nevertheless, been well and long prepared, despite the undoubted truth that the citystate possessed neither a jurisprudence in any proper acceptation of that term, nor yet an authoritatively written constitution, the sole evidence of law fundamental, to which public appeal could be made, being the $\alpha{ }^{\prime} \xi \circ \varepsilon \varepsilon 5$ or $\varkappa v^{\prime} \rho \beta \varepsilon t 5$, whose graven terms hanging in the prytaneion were supposed to be familiar to every citizen and whose provisions were firmly secured against sudden change through a legislative system of law-committees, together with an ultimate right of appeal to the sovereign people itself in its $\dot{\eta} \lambda_{2} \alpha i \alpha$ by means of the celebrated action $\pi \alpha \rho \alpha \nu \rho \mu \omega \nu \gamma \rho \alpha \varphi \eta \dot{~}$. The Athenian law (vó $\mu \circ 5)$, however, was in effect a very different affair from the enactment which we term statute. From a period, indeed, long antedating authentic history, a board of magistrates 
had been charged with the special duty of publicly recording important judicial utterances $(\tau \dot{a} \theta \dot{\varepsilon} \sigma \mu z \alpha)$ to the end that the principles they announced might, in the absence of a written code, be preserved for enforcement against transgressors. ${ }^{1}$ To these

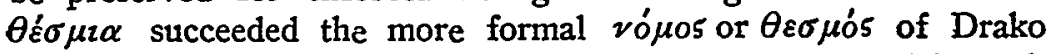
and Solon; the Nomos, however, was intended to accomplish much more than the announcement merely of substantive law, and, beyond question, tended to take on a form closely approximating a distinct constitutional plan ;2 for these laws were, we are told, arranged in groups correspondent with the subjects which they were designed to règulate. Accordingly the Archonship and other departments of State had its special group of Nomoi constituting its organic regulation; and the collection of such groups, was annually laid before the people met in sovereign assembly at the beginning of each Attic year (July-August) in order that public opinion might be taken touching the desirability of any fundamental change. ${ }^{3}$

For a pure democracy such a system presented.ample safeguards, but when in B. C. $4 \mathrm{II}$ a crisis had evidently been reached rendering some radical alteration in government necessary, Athens hesitated to place itself in the hands of the few-or o' $\lambda$ íyor-without the interposition of firmer barriers than the ancient

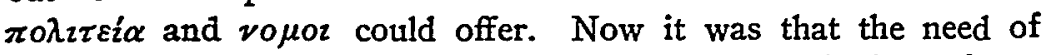
specifically-defined limitation became apparent; a feeling of apprehension not unlike, doubtless, that which was so plainly in evidence at the formation of our own Articles of Confederation and Constitution, led to the greatest care in framing a charter of government. A preliminary board of thirty commissioners laid down

x. These magistrates were the Thesmothetæ (Const. Athens, 3.4). With the thesmia we may compare the Homeric themistes.

2. This most interesting subject is elaborately treated by Busolt (Griechische Geschichte, 2.4I seq.) Denn da Solon nicht bloss Gesetze gab, die das materielle Recht betrafen, sonđern auch Anordnungen traf, die in die Verfassung eingriffen, so konnte er letztere nicht bloss mündlich zur Nachachtung mitteilen, sondern musste sie auch schriftlich feststellen. Freilich hat er keine systematische Verfassungsurkunde entworfen und die staatlichen Einrichtungen, die er vorfand und unverändert liess, in seinen Gesetzen als bestehend vorausgesetzt, aber da er die Gesetze nach den einzelnen Behorden, die sie zu handhaben hatten, zusammenstellte, so wird er gewiss in dem Nomos einer Behörde auch über die Art ihrer Zusammensetzung gehandelt haben, sofern er sie neu geschaffen oder reorganisiert hatte.

3. The grouping is indicated in the document inserted at $\$ 20$ of Demosthenes' speech against Timocrates as the legislative machinery by committees (nomothetae) is detailed at $\S 33$. 
certain basic principles in the nature of bill of rights plainly written out ; ${ }^{*}$ these being approved, a special committee of one hundred proceeded to draw up a formal plan of government, precisely defining powers and duties to be entrusted to the proposed oligarchy, the expression employed in the account which has come down to us being very significant, the commissioners being "they who were to write down the government" Tov's $\dot{\alpha} v \alpha \gamma \rho \alpha \dot{\psi} \psi v \nu \tau \alpha 5 \tau \dot{\eta} v \pi 0 \lambda z \tau \varepsilon i \alpha v,{ }^{5}$ the terms of the written charter being referred to in a subsequent paragraph as $\tau \dot{\alpha} \gamma \varepsilon y \rho \alpha \mu \mu \varepsilon \varepsilon^{\prime} \gamma \alpha^{6}$ this constitution being formally reported ( $\varepsilon \xi \eta \dot{\eta} v \gamma \varkappa \alpha \nu)$, was adopted, while a provisional plan, and that, indeed, under which the Four Hundred were enabled to grasp practically irresponsible power, was expected to pave the way for an ultimate transition to government by council without an assembly and acting only under the limitation of the proposed charter. The entire incident, including the subsequent return to

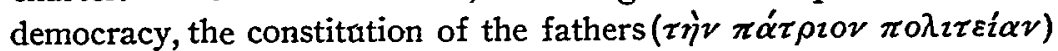
illustrates with the utmost clearness the distinction at which Greek public thought had manifestly arrived in the employment of the term "constitution" $(\pi \circ \lambda \imath \tau \varepsilon i \alpha)$ in the abstract and in the concrete; this is, in fact, the same, distinction with which we are so familiar to-day when we apply the term "constitution" to such a form of government as that of Great Britain on the one hand, and our own upon the other. It is nothing less than the distinction between the immediate presence, as in England, of sovereignty in legislation and administration, and government through a representation, as in the United States, acting under written limitations-in other words, the modern written constitution.

A similar constitutional spirit manifests itself in the carefully drawn declaration, passed upon the formation of the general defensive alliance of $378-377$ B. C. and preserved through the sure medium of an inscription. A notable feature of this marble is the denouncement of high treason upon the magistrate or private citizen who attempts any derogation from its provisions; all such action, in the language of to-day, is, in other words, made "null and void." Such a prohibition was not, however, a novelty in Greek public law; it occurs in the charter of Brea, ${ }^{8}$ B. C. $444-440$,

4, "They ordered the (new) government according to this plan," says the

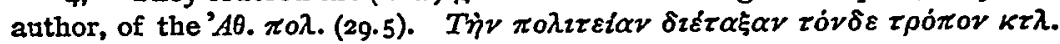

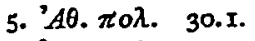

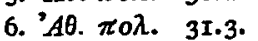

7. Hicks, Manual of Greek Historical Inscriptions (Oxford, 1882), p. 138, seq. No. $8 \mathrm{I}$.

8. Hicks, p. 37 , No. 29. 
and in the decree passed by the Opuntian Lockrians at the colonzation of Naupaktos ${ }^{2}$ (inc. 403 B. C.) ; the last named regulation specially providing for a judicial determination, touching any claimed infringement of the constitution, thus exhibiting a perfect analogue of our own system.

Under widely differing political conditions, but with essentially similar constitutional aims, it was sought on two notable occasions in English history, to place the kingdom under the limitation of a definite scheme of written fundamental law. The first of these occasions arose through the struggle to limit the Crown in a firmer manner than experience had shown could be accomplished through the numerous so-called "charters," whose promises were as easily broken as made; and the magnates, who in 1258 and 1264 , devised the constitutional plans, known as the Provisions of Oxford and the Forma regiminis domini regis et regni, ${ }^{10}$ displayed not only a keen apprehension of the political necessities of the thirteenth century, but a thorough grasp as well of the conception of limited government. Nor should it for a moment be supposed that the constitutional aims which here found such remarkable expression were the result of any sudden illumination; they were, in fact, but the legitimate product of a slowly developing consciousness of the innate and indefeasible supremacy of laze. Law it is, which to the more deeply thinking minds of that age, demands homage as the true sovereign through whose prescriptions the king governs:

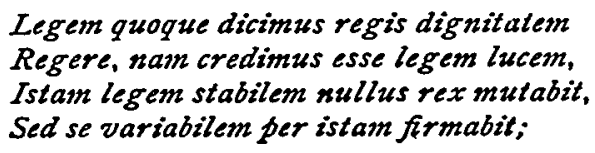

sings the author of the celebrated song of Lewes ${ }^{11}$ his poem, we may note, is precisely co-temporaneous with the latter of our two constitutional documents whose brief existence was foreclosed with the fall at Evesham, of Simon de Montfort, August 4, I265.

Four centuries later, in the days of the coming commonwealth, the public mind had again turned to the idea of law, as its refuge against royal oppression, and, as in the time of the Barons, an elaborate plan, the "Heads of the Proposals,"12 was expected to

9. Hicks, p. II7, No. 63 .

ro. Stubbs, Select Charters (3rd ed.) p. $387,413$.

II. The Song of Lewes, edited by C. L. Kingsford, lines 848-849 and 867868 (Oxford, Clar. Press, I8go).

12. August I, 1647. The Agreement of the People "was originally drawn up in October, I647," though not finally approved until two weeks prior to the death of the king; the Instrument of Government came later, December 16, 
hold in check entrenched despotism. When, shortly afterwards, with the abolition of royalty, the Parliament, the people's "Representative," threatened an advent of tryanny under another form, the agreement of the people and the instrument of the government were looked to as fundamentals, whose authority should underlie legislators: "But some things are Fundamentals," said Cromwell in the Painted Chamber, at Westminster, September I2, 1654, "about which I shall deal plainly with you; these may not be parted with; but will, I trust, be delivered over to posterity ... The government by a single person and a parliament is a fundamental, it is the esse, it is constitutire... As the instrument doth express it, you may make any laws; and if I give not my consent, within twenty days, to the passing of your laws, they are ipso facto laws whether I consent or no; if not contrary to the 'Frame of Government." "

January 22, 1655 , Cromwell reminds members of the House that the people expected it to do things "in pursuance of the Instrument of Government...this Government called you hither," said he, "the constitution thereof being limited so ... it has been already submitted to the judicious, true and honest people of this nation . . . and what their judgment is, is visible, by submission to it; by acting upon it; by restraining their trustees from meddling with it. And it neither asks nor needs any better ratification.... I will say this to you for myself ... that I would not have been averse to any alteration of the good of which I might have been convinced although I could not have agreed to the taking it off the foundation on which it stands; namely, the acceptance and consent of the People."13 It needs, truly, but little effort of the imagination to suppose that we are here listening to an exhortation addressed to the Congress of the United States, reminding that body that its authority is as limited as that of an English legislature was intended to be, under the Instrument whose terms expressly provided, "that all laws, statutes and ordinances, and clauses in any law,

1653-Gardiner, Const. Documents of the Puritan Revolution (p. 232-270-314), who, however, fails to appraise these documents at their full value in a constitutional sense. "The army," says the learned editor in his introduction, "could take care that a man like Charles I should not rule England, but the Agreement of the People, the Instrument of Government and the Humble Petition and Advice were but academical studies, interesting as anticipating in many respects the constitutional and political history of America, but utterly incapable of commending themselves to the conscience of contemporaries.

13. Carlyle's Cromwell, 2, part 8, p. I20 seq. 
statute or ordinance to the contrary of the aforesaid liberty, shall be esteemed as null and void."14

It is certainly of the last importance to the student of constitutional history to remember that it was the highly trained legal consciousness of the seventeenth century, which had developed in an extraordinary manner, plans and details of constitutional limitation, to which we owe the colonial charter, an instrument so wisely elaborated that it was not only the general conception giving it birth which was to survive, but, in two instances at least, the very terms of these charters themselves drawn, perhaps, by the same hands employed but a few years previously to pen the documents of the Puritan revolution, were afterwards deemed worthy long to subsist as the constitutional basis of independent state governments beyond the Atlantic.

Gordon E. Sherman.

I4. Instrument of Government, $\$ 38$. The development of the conception of the supremacy of law, through the early years of the seventeenth century, together with the growing idea of the common law's imprescriptible title to reverence, are sketched by Mr. J. N. Figgis in his "Divine Right of Kings" (Cambridge University Press, 1896, p. 226 seq.).

Cromwell's use of the term, "Frame of Government," is paralleled in the Pennsylvania Charter of r682-"Frame of Government"-and the same nomenclature reappears in the Pennsylvania State Constitution of I776- " Plan or Frame of Government." Here the term finds employment in a concrete sense; with this we may contrast Clarendon's expression, "The frame and constitution of the kingdom" (Hist. of the Rebellion, Book 4. sec. 40), where it denotes, of course, the unwritten English Constitution or form of government. 